\title{
Impact of Accounting Information System on Internal Audit Quality: Mediating Role of Organizational Culture
}

\author{
Qasim Ahmad Alawaqleh ${ }^{1}$ \\ ${ }^{1}$ Accounting Department, Philadelphia University, Jordan \\ Correspondence: Qasim Ahmad Alawaqleh, Accounting Department, Philadelphia University, Jordan.
}

Received: September 6, 2020

Accepted: October 16, 2020

Online Published: December 24, 2020

doi:10.5430/ijfr.v12n1p205

URL: https://doi.org/10.5430/ijfr.v12n1p205

\begin{abstract}
This study advances the Accounting Information System (AIS) study by exploring the relationship between the AIS internal audit quality. It develops a model based on literature and considers one significant variable of mediation that is organizational culture. The AIS is expected to influence internal audit quality in different contexts, particularly in developing countries. The research model validated using AMOS and SPSS version 25. Based on a sample of 183 internal auditors in Jordanian industrial SMEs, empirical findings support the relationship between AIS and internal audit quality; however, the impact is direct while the organizational culture partially mediates this relationship. The results indicate that the AIS help enhance internal auditors' quality and the organizational culture, ultimately improving internal audit quality. The implications are useful for academics, administrators, and policymakers interested in evaluating the impact of intervening variables on the AIS and the internal audit quality relationship.
\end{abstract}

Keywords: accounting information system, internal audit quality, organizational culture, industrial SMEs, Jordan

\section{Introduction}

Accounting Information Systems (AIS) is a mechanism developed to aid in the management and control of matters related to the economic-financial domain of businesses when integrated into the field of Information Technology (IT). This refers to helping the organizations monitor and manages financial irregularities and bankruptcies by diagnosing and orderly, defining them to determine and improve productivity and monitor risk management (Sahawneh, Hayek, \& Bshayreh, 2016). AIS is one of the organization's most important technologies that have changed how it collects, manages, stores, and disseminates information (Wibisono \& Setyohadi, 2017).

AIS are essential for the management of an enterprise and the implementation of internal control systems. Accounting irregularities and financial reporting fraud have exposed inefficiency in internal controls (Bento Regina, Mertins, \& White Lourdes, 2018; Rubino, Vitolla, \& Garzoni, 2017). The ineffective implementation of internal control is once the factor that AIS has not qualified (FITRIATI, SUSANTO, \& Technology, 2017). Thus, the AIS are seen as essential for successful corporate decision-making and management, which play a crucial role in internal auditors' functions and quality (Susanto, 2018). Internal control is used to shield the company from risk or mitigate the risk events' effects. Internal control needs to be incorporated into the information system to ensure financial statements (Chen, Yang, Zhang, \& Zhou, 2020). Low-quality auditing leads to business loss, which in turn can lead to other outcomes like a business failure, corruption, and so on. Failed audits led to discussions about the new replacements to be implemented to ensure consistency of the audit (Knechel \& Salterio, 2016). Internal auditing activities measure the efficacy of the internal control system, where the concept of internal auditing often requires management intervention reviews to address circumstances that vary from those achieved (D'Onza \& Sarens, 2018).

Many scholars have described the usefulness of the internal audits goals and objectives (IA), although they have been interpreted in several ways. A recent study by McNeil et al. (2016) looked at the vital role of culture in various parts of the world. Organizational culture is a crucial element that influences and defines audit consistency (Cole \& Martin, 2018; Tomic et al., 2016). An analysis of current literature indicates a consensus that the quality of internal audits is directly affected by the prevailing work environment and values (Bergh, Hinna, Leka, \& Zwetsloot, 2016; Jespersen, Hohnen, \& Hasle, 2016; Lenning \& Gremyr, 2017).

Small and Medium-Sized Enterprises (SMEs) play a significant part in the economy in the industrial sector. The success of industrial SMEs is closely related to the economic development of individual nations. In particular, SMEs 
in the Jordanian industrial sector have been chosen because of many businesses. Industrial SMEs account for 10\% of Jordan's GDP (JEGP, 2018).

While several studies of internal audit quality research have been conducted, the researcher's awareness of the relationship between AIS and internal audit quality is still limited due to the changing organizational culture. However, there is a lack of empirical research based on AIS and internal audit quality in developing countries. As a result, this study explores the mediating impact of the organizational culture on the relationship between AIS and internal audit efficiency in the Jordanian industrial business. The findings of this research would be useful in designing effective operational strategies for local companies.

The rest of the paper is structured as follows; the literature review and the proposed conceptual model are set out in section 2. Section 3 sets out the research method that has driven research analysis. The results are given in Section 4. Finally, Section 5 provides for a detailed analysis of the main findings and concludes the paper.

\section{Literature Review and Research Model}

Understanding of the AIS, internal audit quality and organizational culture factors have drawn significant interest in prior literature (Abdelahi, Arumugam, \& Suppiah, 2020; Al-Okaily, Al-Okaily, Shiyyab, \& Masadah, 2020; White, Bailey, \& Asenova, 2020). The subsections illustrated the relationships between the research constructs.

\subsection{AIS and Internal Audit Quality}

AIS refers to systems operating data collection functions, processing, classification, and reporting financial activities to provide relevant information to maintain outcomes, guiding knowledge and decision-making (Brandas, Megan, \& Didraga, 2015). The accounting documents' qualitative characteristic may also be preserved if an entity has a successful internal audit framework. Effective audit control helps the management of companies to use more positive information to conduct their business practices correctly and to assess the efficiency of the company (Turner, Weickgenannt, \& Copeland, 2020).

Internal audit primary role in performing transactions financial reporting process and such AIS frameworks supported them in their work (Trigo, Belfo, \& Estébanez, 2016). In the context of the relationship between AIS and internal audit quality, the previous studies found that AIS has a significant impact on internal audit quality (Almaliki, Rapani, Khalid, \& Sahaib, 2019; Ogundana, Ojeka, Ojua, \& Nwaze, 2017; Rapani \& Malim, 2018). As a result, it found that the AIS have a profound impact on the efficacy of internal audit and internal control within organizations.

\subsection{Organizational Culture and Internal Audit Quality}

Organizational culture is also seen as a collection of core beliefs and values held by members of an organization (Kaouache, Brewer, \& Kaouache, 2020). If these beliefs and values are clearly defined and firmly held, culture is considered a robust culture (Stephan \& Pathak, 2016). Organizational culture is at the core of the organization's operations and affects its overall performance and the quality of its product/service (Salih \& Hla, 2017). The literature on culture and audit process believes that the country's culture affects its audit environment, which eventually influences the audit process (Abdelahi et al., 2020). The previous studies showed that the organizational culture has a substantial effect on the quality of internal audit in the sense of the relationship between organizational culture and the internal audit quality (Abdelahi et al., 2020; Alzeban, 2014; Kaouache et al., 2020; Salih \& Hla, 2017). As a result, the culture has had a significant influence on internal auditing quality within organizations.

\subsection{AIS and Organizational Culture}

The organizational culture element is the foundation for the best performing accounting information system (HA, 2020). Culture plays a significant role in developing a standard system of accounting information (Kwarteng \& Aveh, 2018). The previous studies showed significant relationships between AIS and organizational culture (Aldegis, 2018; HA, 2020; Kwarteng \& Aveh, 2018). As a result, the AIS have a significant impact on the culture of the organization. The organizational culture element is the foundation for the best performing accounting information system (HA, 2020). Culture plays a significant role in developing a standard system of accounting information (Kwarteng \& Aveh, 2018). The previous studies showed significant relationships between AIS and organizational culture (Aldegis, 2018; HA, 2020; Kwarteng \& Aveh, 2018). As a result, the AIS have a major impact on the culture of the organization.

\section{Research Model and Hypotheses}

There are numerous studies examining internal audit quality, including organizational culture and AIS (Abdelahi et al., 2020; Aldegis, 2018; Almaliki et al., 2019; Alzeban, 2014; HA, 2020). An analysis of the existing studies found that organizational culture and AIS play an important effect on internal audit quality. The research model is illustrated in figure 1, for examining the mediating role of organizational culture on the relationship between AIS and 
internal audit quality in Jordanian industrial SMEs.

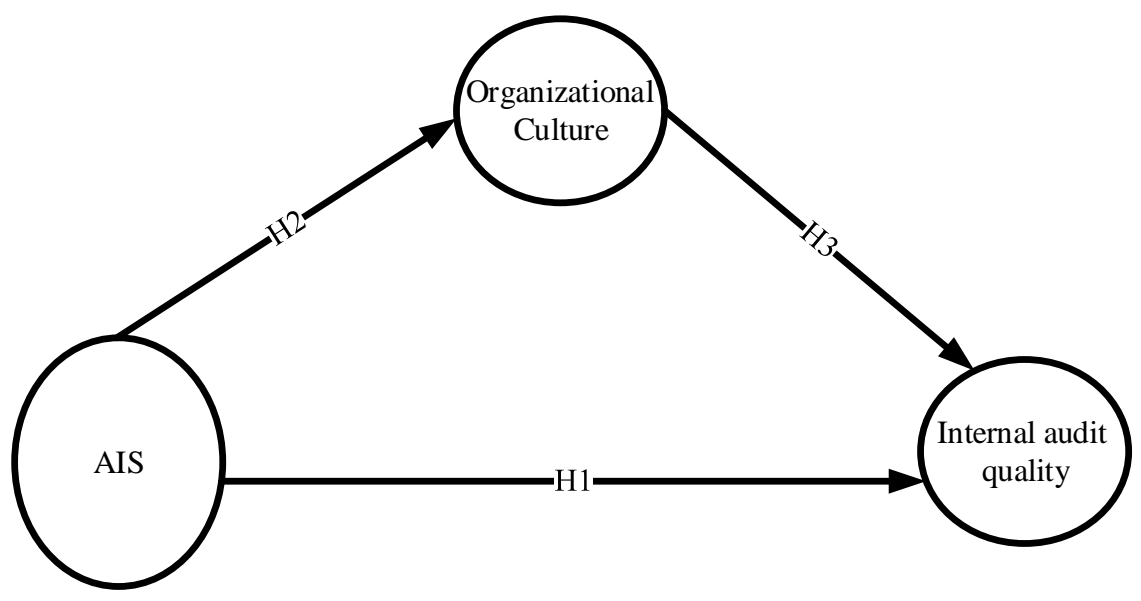

Figure 1. Research model

Based on the analysis of previous studies, the hypotheses of this research are:

H1: AIS has a positive effect on internal audit quality.

H2: AIS has a positive effect on organizational culture.

H3: Organizational culture has a positive effect on internal audit quality.

H4: Organizational culture has a positive effect on the relationship between AIS and internal audit quality.

\section{Method}

The data were gathered using a questionnaire; it consists of 12 questions regarding the research factors adopted from previous studies. For instance, AIS includes 4 adapted from Ayoub, Potdar, Rudra, and Luong (2020) and (Napitupulu, 2018), organizational culture include 4 items adapted from González-Rodríguez, Martín-Samper, Köseoglu, and Okumus (2019), Adeinat Iman and Abdulfatah Fatheia (2019), and Di Stefano, Scrima, and Parry (2019); and internal audit quality items adapted from Agyei-Mensah Ben (2019), Dao, Xu, and Liu (2019), and Beck, Gunn, and Hallman (2019). The respondents were asked to test their insight into the five-point Likert-scale research frameworks in which 5 symbolized 'strongly agree,' 4 symbolized 'agree,' 3 symbolized 'Neutral,' 2 symbolized 'Disagree,' and 1 symbolized 'Strongly disagree.' The questionnaire has been circulated to internal auditors of Jordanian industrial SMEs to evaluate their responses. Data were collected using the survey questionnaire. For sampling the respondents, a random sampling technique was used. A total of 240 questionnaires were distributed; only 183 were available; the response rate was $76.3 \%$. The survey was performed in the conventional manner in which the participants were handed out the questionnaires in person. Due to the adequacy context, distribution assumptions, sample size, and design requirements, this study applied the AMOS and SPSS version 25.

\section{Result}

\subsection{Measurement Model}

Measurement by Kaiser-Mayer-Olkin (KMO) of all factor loadings was greater than 0.50 . The Cronbach alpha was used for internal consistency checking, with the variables described in Table 1. The overall condition at the cut-off was 0.7 . Thus, the overall values were above 0.7 , showing that the overall scale and the factors derived are adequate reliability (Al Shbail, Salleh, \& Nor, 2018; Obeid, Salleh, \& Nor, 2017; Sl Shbail, Salleh, Nor, \& Nazli, 2018). The structural models were used as well as the measurement estimates. Thus, the content validity of the research constructs is presumed (see table 1). The Confirmatory Factor Analysis (CFA) was used for checking the convergent validity; The CFA results (RMSEA $=0.066$; $\mathrm{NFI}=0.903 ; \mathrm{CFI}=0.954 ; \mathrm{p}=0.000$ ) suggested that the overall indices matched very well with the data and concluded that the research model is satisfactory (see Figure 2). 


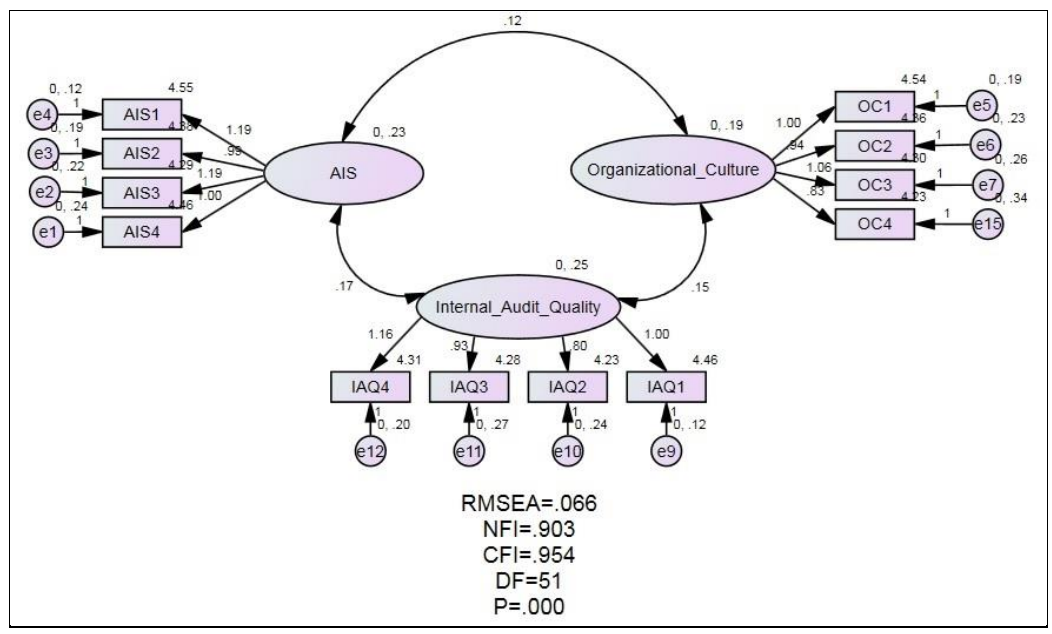

Figure 2. Measurement model

Table 1. Measurements reliability and validity

\begin{tabular}{|c|c|c|c|c|}
\hline Constructs & Items code & Factor loading & KMO & $\begin{array}{l}\text { Cronbach's } \\
\text { Alpha }\end{array}$ \\
\hline \multirow[t]{4}{*}{ AIS } & AIS1 & .864 & \multirow[t]{4}{*}{.802} & \multirow[t]{4}{*}{.854} \\
\hline & AIS2 & .816 & & \\
\hline & AIS3 & .854 & & \\
\hline & AIS4 & .803 & & \\
\hline \multirow{4}{*}{$\begin{array}{l}\text { Organizational } \\
\text { culture }\end{array}$} & OC1 & .784 & \multirow[t]{4}{*}{.742} & \multirow[t]{4}{*}{.729} \\
\hline & OC2 & .755 & & \\
\hline & OC3 & .789 & & \\
\hline & OC4 & .745 & & \\
\hline \multirow{4}{*}{$\begin{array}{ll}\text { Internal audit } \\
\text { quality }\end{array}$} & IAQ1 & .844 & \multirow[t]{4}{*}{.771} & \multirow[t]{4}{*}{.815} \\
\hline & IAQ2 & .736 & & \\
\hline & IAQ3 & .783 & & \\
\hline & IAQ4 & .848 & & \\
\hline
\end{tabular}

\subsection{Hypothesis Testing}

Structural Equation Modeling (SEM) using AMOS was employed to test the hypothesized construct. This study explored the structural model through AIS (as an exogenous construct), organizational culture, and internal audit quality (as endogenous constructs). Estimates of the structural coefficient provide the basis for evaluating the proposed hypotheses.

The AIS significantly and positively impacts the internal audit quality $(\beta=.724, C . R=7.383, p<0.01)$, as illustrated in figure 3 and table 2. Thus the H1 is supported. This finding is consistent with Almaliki et al. (2019) and Rapani and Malim (2018). 


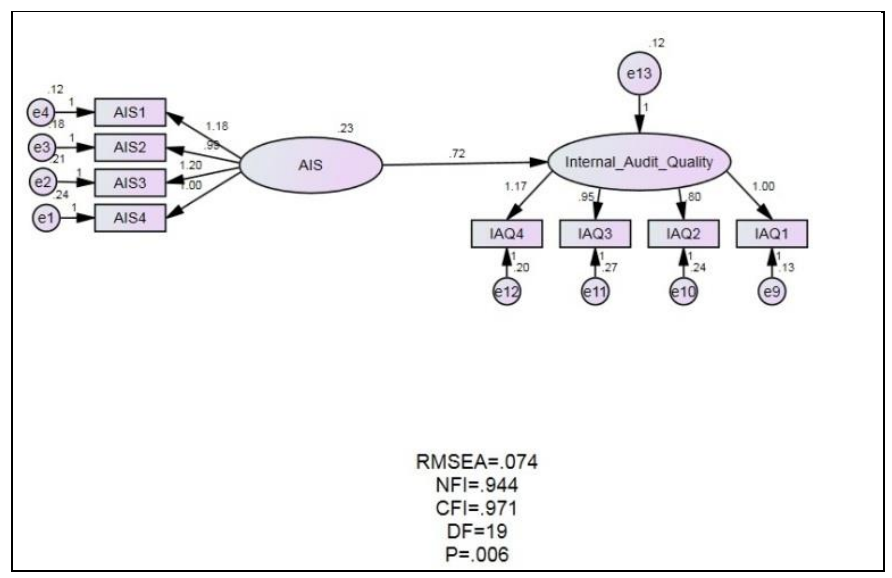

Figure 3. Result of Hypothesis 1

Table 2. Result of Hypothesis 1

\begin{tabular}{|c|c|c|c|c|c|c|c|}
\hline Relationship & & & Estimate & S.E. & C.R. & $\mathrm{P}$ & Decision \\
\hline Internal_Audit_Quality & $<---$ & AIS & .724 & .098 & 7.383 & $* * *$ & supported \\
\hline
\end{tabular}

Regarding H2, this research found that AIS significantly and positively impacts the organizational culture ( $\beta=.489$, C.R=5.411, $\mathrm{p}<0.01$ ), as illustrated in figure 4 and table 3 . Thus the $\mathrm{H} 2$ is supported. This finding is supported by Ali, Omar, and Bakar (2016).

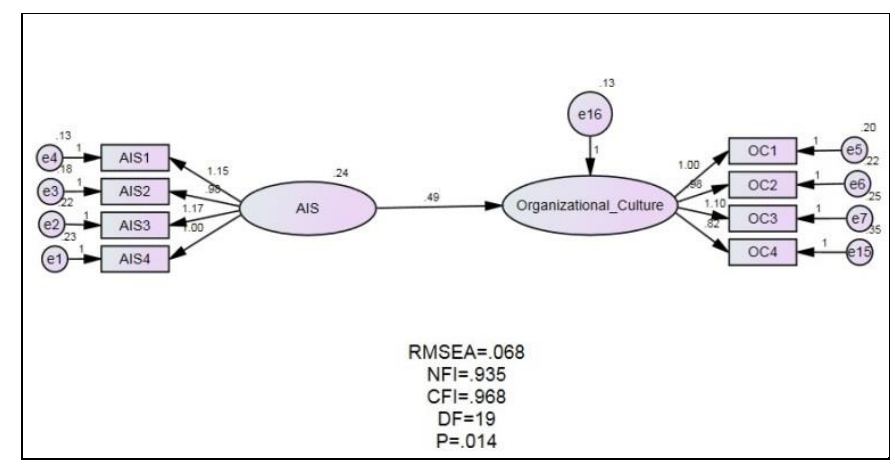

Figure 4. Result of Hypothesis 2

Table 3. Result of Hypothesis 2

\begin{tabular}{|c|c|c|c|c|c|c|c|}
\hline Relationship & & & Estimate & S.E. & C.R. & $\mathrm{P}$ & Decision \\
\hline Organizational_Culture & $<--$ & AIS & .489 & .090 & 5.411 & *** & supported \\
\hline
\end{tabular}

Further analysis showed that organizational culture positively impacted the internal audit quality ( $\beta=.749, \mathrm{C} . \mathrm{R}=6.375$, $\mathrm{p}<0.01$ ), as illustrated in figure 5 and table 4 . Thus the $\mathrm{H} 3$ is supported. This study supports evidence from previous observations (Alzeban, 2014). 


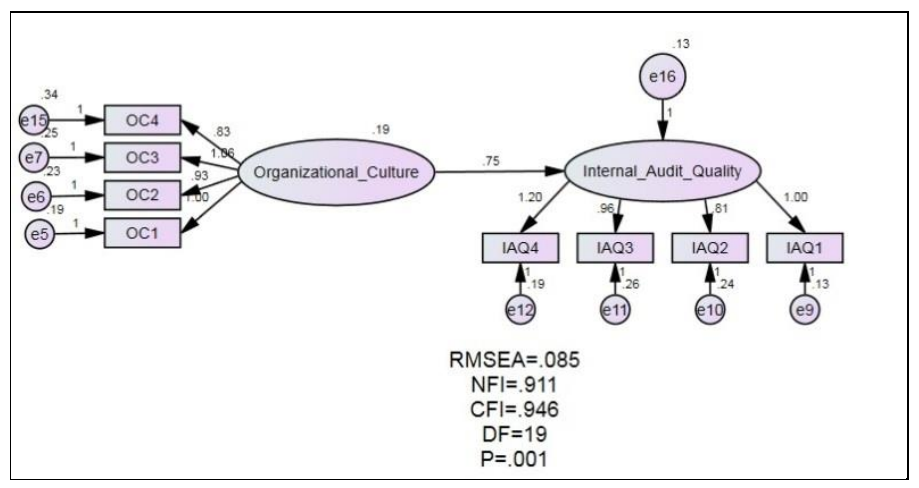

Figure 5. Result of Hypothesis 3

Table 4. Result of Hypothesis 3

\begin{tabular}{lccccccc}
\hline Relationship & & & Estimate & S.E. & C.R. & P & Decision \\
\hline Internal_Audit_Quality & $<---$ & Organizational_Culture & .749 & .117 & 6.375 & $* * *$ & supported \\
\hline
\end{tabular}

Moreover, to observe the mediator role of organizational culture on the relationship between AIS and internal audit quality. The first phase involved the inclusion of the research constructs (AIS, organizational culture and internal audit quality (see figure 6 and Table 5), inclusion of the mediator construct (organizational culture) decreased the value of $\beta$ and C.R in the relationship between AIS and internal audit quality $(\beta=.496, C . R=4.933, p>0.01)$. This indicates that organizational culture plays a partial mediation on the relationship between AIS and internal audit quality; thus, H4 is supported. This finding is in agreement with this obtained by (Hoque, 2018).

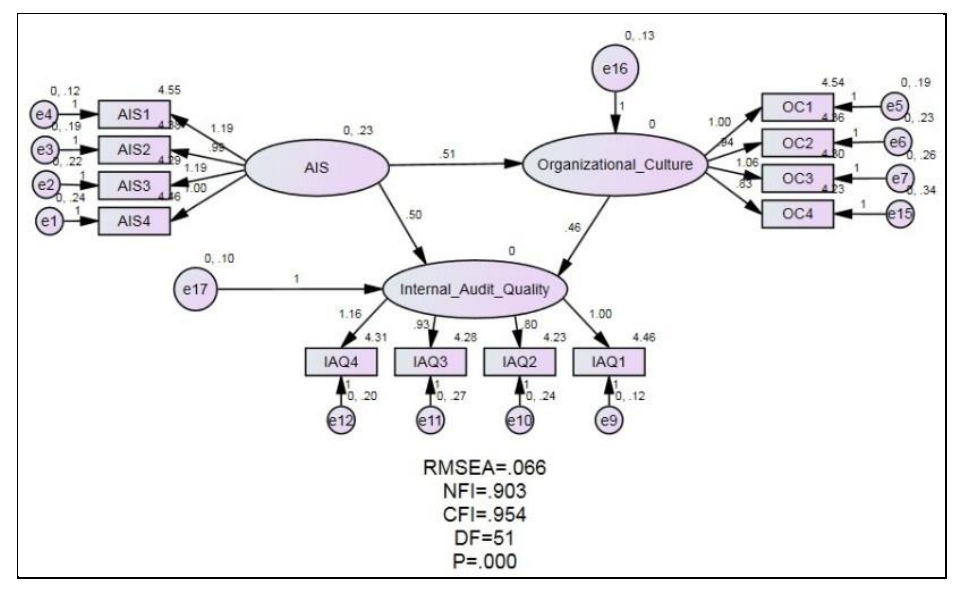

Figure 6. Result of Hypothesis 4

Table 5. Result of Hypothesis 4

\begin{tabular}{llllllll}
\hline Relationship & & & Estimate & S.E. & C.R. & P & Decision \\
\hline Organizational_Culture & $<--$ & AIS & .513 & .093 & 5.520 & $* * *$ & \\
\cline { 1 - 6 } Internal_Audit_Quality & $<---$ & AIS & .496 & .101 & 4.933 & $* * *$ & \multirow{2}{*}{ supported } \\
\cline { 1 - 6 } Internal_Audit_Quality & $<---$ & Organizational_Culture & .460 & .115 & 4.008 & $* * *$ & \\
\cline { 1 - 5 }
\end{tabular}




\section{Conclusion}

This research purpose was to propose and establish a conceptual model for AIS and internal audit efficiency and validate its structure in Jordan's industrial SMEs. The validation and reliability analysis showed further reliability of the model and its constructs. This study explored organizational culture as a mediator between AIS and internal audit quality and found that the organizational culture plays a significant role in such a relationship and is stated to be partially mediated by organizational culture. This research finding provides empirical evidence that supports AIS's important position in audit quality and organizational culture. This research has practical consequences for practitioners and managers. It provides practitioners with the knowledge required to enhance the audit quality of any organization. It indicates that AIS and organizational culture in SMEs are essential elements for the quality of the audit. It allows SME management to know what factors are critical for improving internal auditors' quality. Therefore further studies should be performed to connect the relationship between the AIS and the internal audit quality. It is expected to focus on the other variables for future research and compare the results with the other industry instead of the survey study.

\section{References}

Abdelahi, A. H., Arumugam, D., \& Suppiah, K. A. (2020). Behavioral Aspect: The Impact of Organization Culture and Ethicality on Internal Auditor's Decision Making. International Journal of Psychosocial Rehabilitation, 24(2).

Adeinat Iman, M., \& Abdulfatah Fatheia, H. (2019). Organizational culture and knowledge management processes: a case study in a public university. VINE Journal of Information and Knowledge Management Systems, 49(1), 35-53. https://doi.org/10.1108/VJIKMS-05-2018-0041

Agyei-Mensah Ben, K. (2019). The effect of audit committee effectiveness and audit quality on corporate voluntary disclosure quality. African Journal of Economic and Management Studies, 10(1), 17-31. https://doi.org/10.1108/AJEMS-04-2018-0102

Al Shbail, M. O., Salleh, Z., \& Nor, M. N. M. (2018). The effect of ethical tension and time pressure on job burnout and premature sign-off. Journal of Business Retail Management Research, 12(4).

Aldegis, A. M. (2018). Impact of Accounting Information Systems' Quality on the Relationship between Organizational Culture and Accounting Information in Jordanian Industrial Public Shareholding Companies. International Journal of Academic Research in Accounting, Finance Management Sciences, 8(1), 70-80.

Ali, B. J., Omar, W. A. W., \& Bakar, R. (2016). Accounting Information System (AIS) and organizational performance: Moderating effect of organizational culture. International Journal of Economics, Commerce, and Management, 4(4), 138-158.

Almaliki, O. J., Rapani, N. H. A., Khalid, A. A., \& Sahaib, R. M. (2019). Structural equation model for the relationship between accounting information system and internal audit effectiveness with the moderating effect of experience. International Business Education Journal, 12, 62-82.

Al-Okaily, A., Al-Okaily, M., Shiyyab, F., \& Masadah, W. (2020). Accounting information system effectiveness from an organizational perspective. Management Science Letters, 10(16), 3991-4000.

Alzeban, A. (2014). The Impact of Culture on the Quality of Internal Audit: An Empirical Study. Journal of Accounting, Auditing \& Finance, 30(1), 57-77. https://doi.org/10.1177/0148558X14549460

Ayoub, A., Potdar, V., Rudra, A., \& Luong, H. (2020). The Impact of Organizational Culture on the Internal Controls Components of Accounting Information Systems in the City of Beirut, Lebanon. Paper presented at the Big Data and Security, Singapore.

Beck, M. J., Gunn, J. L., \& Hallman, N. (2019). The geographic decentralization of audit firms and audit quality. Journal of Accounting and Economics, 68(1), 101-234. https://doi.org/10.1016/j.jacceco.2019.101234

Bento Regina, F., Mertins, L., \& White Lourdes, F. (2018). Risk Management and Internal Control: A Study of Management Accounting Practice. In A. M. Mary (Ed.), Advances in Management Accounting (Vol. 30, pp. 1-25). Emerald Publishing Limited.

Bergh, L. I. V., Hinna, S., Leka, S., \& Zwetsloot, G. I. J. M. (2016). Developing and testing an internal audit tool of the psychosocial work environment in the oil and gas industry. Safety Science, 88, 232-241. https://doi.org/10.1016/j.ssci.2015.06.003 
Brandas, C., Megan, O., \& Didraga, O. (2015). Global Perspectives on Accounting Information Systems: Mobile and Cloud Approach. Procedia Economics and Finance, 20, 88-93. https://doi.org/10.1016/S2212-5671(15)00051-9

Chen, H., Yang, D., Zhang, X., \& Zhou, N. (2020). The Moderating Role of Internal Control in Tax Avoidance: Evidence from a COSO-Based Internal Control Index in China. The Journal of the American Taxation Association, 42(1), 23-55.

Cole, J., \& Martin, A. J. (2018). Developing a winning sports team culture: organizational culture in theory and practice. Sport in Society, 21(8), 1204-1222. https://doi.org/10.1080/17430437.2018.1442197

Dao, M., Xu, H., \& Liu, L. (2019). Impact of the disclosure of audit engagement partners on audit quality: Evidence from the USA. International Journal of Auditing, 23(1), 112-124. https://doi.org/10.1111/ijau.12149

Di Stefano, G., Scrima, F., \& Parry, E. (2019). The effect of organizational culture on deviant behaviors in the workplace. The International Journal of Human Resource Management, 30(17), 2482-2503. https://doi.org/10.1080/09585192.2017.1326393

D'Onza, G., \& Sarens, G. (2018). Factors that enhance the quality of the relationships between internal auditors and auditees: Evidence from Italian companies. International Journal of Auditing, 22(1), 1-12. https://doi.org/10.1111/ijau.12100

Fitriati, A., Susanto, A. J. J. O. T., \& Technology, A. I. (2017). The accounting information system quality improvement through internal control and top management support effectiveness. Journal of Theoretical and Applied Information Technology, 95(19).

González-Rodríguez, M. R., Martín-Samper, R. C., Köseoglu, M. A., \& Okumus, F. (2019). Hotels' corporate social responsibility practices, organizational culture, firm reputation, and performance. Journal of Sustainable Tourism, 27(3), 398-419. https://doi.org/10.1080/09669582.2019.1585441

HA, V. D. (2020). Impact of organizational culture on the accounting information system and operational performance of small and medium sized enterprises in Ho Chi Minh City. The Journal of Asian Finance, Economics, Business, 7(2), 301-308.

Hoque, A. (2018). The effect of entrepreneurial orientation on Bangladeshi SME performance: Role of organizational culture. International Journal of Data Network Science, 2(1), 1-14.

JEGP. (2018). Technical guide for pre-selection of public investment projects.

Jespersen, A. H., Hohnen, P., \& Hasle, P. (2016). Internal audits of psychosocial risks at workplaces with certified OHS management systems. Safety Science, 84, 201-209. https://doi.org/10.1016/j.ssci.2015.12.013

Kaouache, R., Brewer, G. A., \& Kaouache, D. E. (2020). Existing and preferred organizational culture in public organizations: The case of an electric power plant in Algeria. Journal of Transnational Management, 25(2), 154-171. https://doi.org/10.1080/15475778.2020.1734420

Knechel, W. R., \& Salterio, S. E. (2016). Auditing: Assurance and risk. Taylor \& Francis.

Kwarteng, A., \& Aveh, F. (2018). An empirical examination of organizational culture on an accounting information system and corporate performance: Evidence from a developing country perspective. Meditari Accountancy Research, 26(4), 675-698. https://doi.org/10.1108/MEDAR-01-2018-0264

Lenning, J., \& Gremyr, I. (2017). Making internal audits business-relevant. Total Quality Management \& Business Excellence, 28(9-10), 1106-1121. https://doi.org/10.1080/14783363.2017.1303891

McNeil, J. C., Forbes, A. R., Vallejo, J. G., Flores, A. R., Hultén, K. G., Mason, E. O., \& Kaplan, S. L. (2016). Role of operative or interventional radiology-guided cultures for osteomyelitis. Pediatrics, 137(5), e20154616.

Napitupulu, I. H. (2018). Organizational Culture in Management Accounting Information System: Survey on State-owned Enterprises (SOEs) Indonesia. Global Business Review, 19(3), 556-571. https://doi.org/10.1177/0972150917713842

Obeid, M., Salleh, Z., \& Nor, M. N. M. (2017). The mediating effect of job satisfaction on the relationship between personality traits and premature sign-off. Academy of Accounting Financial Studies Journal.

Ogundana, O., Ojeka, S., Ojua, M., \& Nwaze, C. (2017). Quality of Accounting Information and Internal Audit Characteristics in Nigeria. Journal of Modern Accounting Auditing, 13(8), 333-344. 
Rapani, N. H. A., \& Malim, T. (2018). The Effect of Accounting Information System on Internal Audit Effectiveness; Testing the Moderating Role of Experience. Jour of Adv Research in Dynamical Control Systems, 10(10).

Rubino, M., Vitolla, F., \& Garzoni, A. (2017). The impact of an IT governance framework on the internal control environment. Records Management Journal, 27(1), 19-41. https://doi.org/10.1108/RMJ-03-2016-0007

Sahawneh, N., Hayek, A. F., \& Bshayreh, M. M. M. (2016). Evaluation of Accounting Information Systems in Meeting the Requirements of Financial and Managerial Performance: Field Study in the United Arab Emirates Private Hospitals. International Journal of Humanities Social Science, 6(4), 170-176.

Salih, W. K., \& Hla, D. T. (2017). Organizational Culture with the Determinants of Quality Assurance to Improve Audit Quality in the Public Sector. Kantakji, (57).

S1 Shbail, M., Salleh, Z., Nor, M., \& Nazli, N. (2018). Antecedents of burnout and its relationship to internal audit quality. Business Economic Horizons, 14(1232-2019-871), 789-817.

Stephan, U., \& Pathak, S. (2016). Beyond cultural values? Cultural leadership ideals and entrepreneurship. Journal of Business Venturing, 31(5), 505-523. https://doi.org/10.1016/j.jbusvent.2016.07.003

Susanto, A. (2018). The quality of accounting information system and its impact on the quality of accounting information: user ability and top management prospective.

Tomic, B., Spasojević Brkić, V., Karapetrovic, S., Pokrajac, S., Milanović, D. D., Babić, B., \& Djurdjevic, T. (2016). Organizational culture, quality improvement tools, and methodologies, and business performance of a supply chain. Proceedings of the Institution of Mechanical Engineers, Part B: Journal of Engineering Manufacture, 231(13), 2430-2442. https://doi.org/10.1177/0954405416629100

Trigo, A., Belfo, F., \& Estébanez, R. P. (2016). Accounting Information Systems: Evolving towards a Business Process Oriented Accounting. Procedia Computer Science, 100, 987-994. https://doi.org/10.1016/j.procs.2016.09.264

Turner, L., Weickgenannt, A. B., \& Copeland, M. K. (2020). Accounting information systems: controls and processes. John Wiley \& Sons.

White, S., Bailey, S., \& Asenova, D. (2020). Blurred lines: exploring internal auditor involvement in the local authority risk management function. Public Money \& Management, 40(2), 102-112. https://doi.org/10.1080/09540962.2019.1667682

Wibisono, Y. P., \& Setyohadi, D. B. (2017). Accounting information system for nonprofit organization based on PSAK 45 standards. Paper presented at the 2017 2nd International conferences on Information Technology, Information Systems and Electrical Engineering (ICITISEE).

\section{Copyrights}

Copyright for this article is retained by the author(s), with first publication rights granted to the journal.

This is an open-access article distributed under the terms and conditions of the Creative Commons Attribution license (http://creativecommons.org/licenses/by/4.0/). 